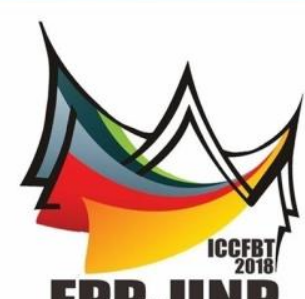

FPP-UNP

PROCEEDING

The $1^{\text {st }}$

ICGFBT 2018

INTERNATIONAL CONFERENCE ON CULINARY.

FASHION, BEAUTY AND TOURISM

Enfigfitening The World Tfurougf ICCEBT 2018

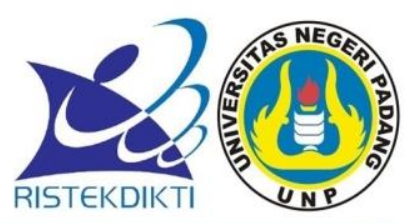

Auditorium Universitas Negeri Padang 


\section{PROCEEDING}

The $1^{\text {st }}$ International Conference on

Culinary, Fashion, Beauty, and Tourism (ICCFBT)

Theme:

“Creative Economic and Sustainable Tourism Towards Digital Globalization”

Padang, May $11^{\text {th }}-12^{\text {th }}, 2018$

Speaker:

Prof. Kaye Chon (Poly U Hongkong)

Prof. Dr. Mohd Salehuddin Mohd Zahari (University Teknologi Mara Malaysia)

Dr. Martha Tilaar (CEO Martha Tilaar Group)

Prof. David Hind (President of The Asia Pasific Institute for Event Management; Distinguished Proffesor at Chung Hua University, Taiwan and Visiting Proffesor at London Metropolitan University, UK)

\section{Fakultas Pariwisata dan Perhotelan Universitas Negeri Padang (FPP UNP)}




\section{PROCEEDING}

The $1^{\text {st }}$ International Conference on

Culinary, Fashion, Beauty, and Tourism (ICCFBT)

Theme:

"Creative Economic And Sustainable Tourism Towards Digital Globalization"

\section{Steering Committee:}

Prof. Ganefri, Ph.D

Dra. Ernawati, M.Pd, Ph.D

\section{Organizing Committee:}

Dr. Elida. M.Pd

Prof. Anni Faridah. M.Pd

Hijriyantomi Suyuthie, S.Ip, MM

Resi Yulia, SE, MM

Dra. Rahmiati, M.Pd, Ph.D

Indralena, SH. M.Pd

Dr. Yuliana, S.P, M.Si

Heru Pramudia, S.ST, M.Par

Pasaribu, SST.Par, M.Si.Par

Medris. S.Kom, M.Cio

Waryono, S.Pd, MM.Par

Dra. Ira Meirina Chair, M.Pd

Murni Astuti, S.Pd, M.Pd.T

Merita Yenita, S.Pd, M.Pd.T

Dra. Wirnelis Syarif, M.Pd

Dra. Lucy Fridayati, M.Kes

\section{CHIEF EDITOR:}

Dr. Yuliana, SP., M.Si

\section{EDITORS AND REVIEWERS:}

1. Prof. Kaye Chon - Poly U Hong Kong

2. Prof. Dr. Mohd. Salahuddin Mohd Zahari - University Teknologi Mara Malaysia

3. Prof. David Hind - Asia Pacific Institute

4. Krismadinata, ST,MT, Ph.D - Universitas Negeri Padang

5. Yohandri, M.Si., Ph. D - Universitas Negeri Padang

6. Dr. Rahadian .Z, S.Pd, M.Si - Universitas Negeri Padang

7. Ifdil, S.HI, S.Pd., M.Pd., Ph.D.Kons

8. Dra. Asmar Yulastri, M.Pd, Ph.D

9. Dr. Yenni ldrus, M.Pd 
10. Dr. Linda Rosalina, M.Biomed

11. Trisna Putra, SS, M.Sc

\section{LAYOUT EDITOR}

Cover

: Tourism and Hospitality Promotions

Content Layout

: Feri Ferdian, SST.,M.M

Hendri Azwar, S.ST Par., M.Par

Drs. Andriwifa, M.Si

\section{Published by}

Fakultas Pariwisata dan Perhotelan

Universitas Negeri Padang (FPP UNP)

Jl. Prof. Dr. Hamka Air Tawar Kota Padang

Sumatera Barat, Indonesia

Telp: 0751-7051186

Email: tourismconference@fpp.unp.ac.id

Website: tourismconference.fpp.unp.ac.id

ISBN 978-602-52249-0-4

All Right Reserved

No Part of Publication May Be Reproduce Without Written Permission of The Publisher 


\title{
EFFECTIVENESS OF MULTIMEDIA BASED LEARNING MEDIA ON BAKERY COURSES
}

\author{
Ezi angraini, Anni faridah \\ Cullinary Art Of Home Economics Department \\ Faculty Of Tourism and Hospitality Universitas Negeri Padang Indonesia \\ ezia321214@gmail.com
}

\begin{abstract}
This study aims to analyze the effectiveness of multimedia-based learning media in bread courses. The type of this research was experiment, which was done on student of cake class of 2014 IKK FPP UNP which was divided into 2 classes that was experiment class and control class. This experiment analyzes the learning outcomes that multimedia provides with those not using multimedia. By conducting an analysis of the control and experimental class results using the paired sample t-formulas (related samples). The results obtained from this study can be concluded that multimediabased learning media on the bread sheet was useful to be used as a medium of learning bakery.
\end{abstract}

KEYWORDS: Effectiveness, Multimedia Based Media Learning, Bakery.

\section{INTRODUCTION}

Improving the quality of education can be done by improving the learning process in educational institutions both schools and colleges. State University of Padang as educational institution of educational personnel who have a mission to improve the quality of education. This quality-oriented education faces many challenges that can not be overcome with the old paradigm but it is indispensable that innovations in learning can develop all dimensions that exist in the learner (Sumardjoko, 2010: 86). Therefore educators should have an attractive learning strategy for learners, through learning methods and using innovative learning media.

In relation to the improvement of the quality of education, the role of lecturers is crucial in the process of quality learning. According to Law Number 14 Year 2005 Article 20 explains that: "Teachers and lecturers' duties are planning lessons, conducting quality learning process, and assessing and evaluating learning outcomes. Learning process is said to be qualified when in the learning process students can achieve the expected learning objectives ".

Lecturers should be able to create an atmosphere of learning that attracts students to follow the lecture so that learning objectives are achieved. The development of science and technology increasingly encourage renewal efforts in utilizing the results of technology in the learning process. The lecturers are required to be able to use the tools that can be provided by the campus and does not cover the possibility that the tools in accordance with the development and demands of the times. Lecturers can at least use cheap and simple tools but are required in order to achieve the expected teaching objectives. Besides beingable to use the tools available, lecturers are also required to develop the skills of making learning media that will be used if the media is not yet available.

In educational institutions, especially Higher Education in Indonesia, problems that often arise can be indicated by learning problems from students in 
understanding the material, especially practice. This indication is likely due to a less effective student learning factor. Learning methods using lectures and percentages only, as well as learning media used are still conventional so that learners less than the maximum in practice resulting in the results of many practices that fail and automatically get remedial or repeat unfinished practices. The same thing also happened at the luncheon of Bakery in the Department of Family Welfare (IKK), Faculty of Tourism and Hospitality State University of Padang.

Pre-research is done when the author as an assistant / assistant lecturer in the course of the Bakery. In this pre-study, the authors felt that it was difficult for a teaching professor to practice relying solely on a once-published jobheet so that the images in the worksheet were less clear step by step. This resulted in the lecturer should explain and exemplify with the details of the steps of lecture practice Bakery, so it takes a longer time in completing the lecture. Lecturers are also overwhelmed to explain the practice materials during the practicum process, because students have not fully grasped the theory given. The lecturer can only explain and demonstrate the practicum procedure 20 minutes at the beginning of the meeting before the practice begins and the rest of the time is spent on practice, assessment and evaluation of the product practiced.

This thus resulted in the results of many student practices are not in accordance with the should / expected. As a result many students fail and have to repeat the practice at the end of semester (remedial). Obviously it is very detrimental both from the students themselves and also the campus because they have to spend more money, and also the loss of time to practice. According to Rusman (2011: 60) learning is a process of communication between learners, teachers and teaching materials.

Communications will not work without the aid of messaging or media. Media used in learning is called learning media, which has a function as an intermediary message, in this case is the subject matter to learners. Rusman (2011: 60) learning media is a tool or a form of stimulus that serves to convey the message of learning. Forms of stimulus can be used as a medium such as relationships or interactions of humans, reality, moving images or not, written and recorded sounds. These five forms of stimulus will help participants in learning a foreign language. Meanwhile, according to Sanjaya (2014: 61) is meant by learning media is everything like tools, environment and all forms of activities that are conditioned to increase knowledge, change attitudes or impart skills to everyone who utilizes it.

Sadiman (2012: 7) media is derived from the Latin and is the plural of the word medium which literally means intermediary or introduction. Media is the intermediary or messenger of the sender to the recipient of the message. Meanwhile, according to Djamarah (2002: 137) in general media is defined as a tool what can be used as a message channel to achieve a goal whether it is the purpose of teaching and other purposes.

According to Wankat \& Oreonovicz, as quoted by Wena (2009: 203), one of the advantages of learning by using computer learning media is that it can stimulate students to do the exercises because of the availability of (1) graphic animation, (2) colors, and (3) music. Computers even notebook or laptop is not a luxury item anymore, so many people who already have a computer. Therefore, computer learning media can facilitate students to learn independently. Students can learn by using computers both at school and at home. 
So, from some opinions above can be concluded that the learning media is any tool or form that serves as an intermediary message to increase knowledge, change attitudes or inculcate benefits, the message is meant here is the subject matter presented to students. Talking about the media and the experiences it builds, we can be guided by the Cone of Experience or commonly called the Cone of Experience.

\section{METHODS}

This research developed a multimedia-based learning media in bakery course. Multimedia-based learning media aims to improve motivation and develop students' understanding of the material delivered, so that students can master every material that teaches well. The procedure of developing multimediabased learning media in bakery course uses 4-D development model (four-D). The development process consists of 4 stages: (1) define (determination of material); design (design); (3) develop (development); (4) disseminate (spread).

Validity of multimedia-based learning media consists of 2 categories, for validity of the media requested to 2 validators who are experts in the field of media, the lecturer FT UNP then for the validity of content / media content validation by lecturers pengont FPP UNP lectures and teacher subjects Pastry And Bakery in SMK. After the next valid media is tested to the students. Trial of multimedia-based learning media in bakery course is held in the Department of Family Welfare Science Faculty of Engineering State University of Padang, the subject of the experiment in this study is a student class of 2014 who took the course of bakery in the semester of July - December 2016. The test subjects consist of 2 classes are experiment class and control class. The research data is obtained from Media Validation Instrument, for Media Expert, Instrument Praktikalitas Media for students and lecturers, and Instrument Effectiveness given to the student, this effectiveness instrument is a matter of posttest and average practice value.

The procedure of developing multimedia-based learning media in bakery course uses 4-D development model (four-D). (Trianto 2009: 189). Research instruments developed to collect data in this study are observation, and questionnaires. Data analysis is done on preliminary data obtained and on data validation result of initial product development by expert (expert). Data analysis technique used is descriptive. With this descriptive technique the researcher will describe or describe the data that has been collected as is without intending to make conclusions that apply to the public or generalization. The uniform appearance will assist the reader to read paper of the proceedings. It is therefore suggested to authors to use the example of this file to construct their papers. This particular example uses an American letter format with $25 \mathrm{~mm}$ margins left, right, top and bottom.

\section{RESULTS AND DISCUSSION}

Bakery courses include theoretical learning as an introduction to practical learning that discusses the development of Bakery's basic recipes. Through a variety of analyzes including basic materials development and recipe development, market development of Bakery products, as well as the development of packaging and display methods, it will produce Bakery products that have high quality and qualified selling price (Ruaida, 2012) 
For IKK FPP UNP subject of Bakery is one of the subjects belonging to the subject of Science and Skill of 3 SKS, this course comes out in every semester of July-December. The development of multimedia-based learning media is a series of processes or activities undertaken to produce an effective multimediabased learning media. The multimedia-based learning media developed is based on the 4-D development model (Define, Design, Develop, Disseminate). This development model was developed by Thiagarajan contained in Trianto's book (2010: 94).

\section{1 . Definition Stage (define)}

This define stage aims to generate and define the basic problems faced in learning, in designing multimedia-based learning media needs to first be analyzed the concepts of the materials used and student analysis.

This stage is a needs analysis, whether it be needs, students, concepts and tasks, where at this stage analysis of learning conditions that occur prior to development. It aims to know the solution and the selection of appropriate strategies as a foundation for developing multimedia-based learning media is expected.

32. Design Phase (design)

After performing initial analysis on define resistance (define) then the next step is the design stage (design). At this design stage there are several activities, namely preparation of tests, media selection, selection of appropriate format and initial design (prototype) of Multimedia-based learning media to be developed.

3 3. Development Stage (develop)

This development stage aims to develop a multimedia-based learning media that is valid, practical and effective. At this stage of development is done two activities, namely the validation of learning media and development trials. Where in the validation activities of media development there are validation activities of Multimedia-based learning media assessed by several validators, whereas in the development trial activities there are practical test activities against multimedia-based learning media conducted by lecturers and students, as well as the effectiveness test of multimediabased learning media .

\section{THE EFFECTIVENESS OF MULTIMEDIATED}

The effectiveness of multimedia learning media in this study is used to facilitate students in understanding learning materials. The effectiveness of multimedia learning media development in Bakery courses by conducting experimental class test and experimental class. According Sugiyono (2006: 407) that research and development methods are research methods used to produce a particular product and test the effectiveness of the product. Thus it can be concluded that the development research is a research method used to develop a product then tested its effectiveness.

Based on data obtained from the result of MID semester / post test test and average practice value during half semester hence the researcher can explain that there are difference of value in result of experiment class and control class. The average MID / post test of the experimental class is 82.53 and the average MID / post test of the control class is 73.01. It can be concluded that there is a 
difference between the classes given multimedia-based media and those not given multimedia.

The average of experiment class practice value is 90 and the mean practice value of control class is 78 . It can be concluded here that there is a difference of experiment class practice grade value with control class. Also, there is a remedial difference between the experimental class and the control class, ie for the experimental class, there is no remedial, while the control class is remedial as much as 8 , with the remedial provision having to repeat the practice at the end of the semester.

In the search for effectiveness by applying the -t test, obtained $t$-count value of 3.93 and t-table of 2.08 , from the value can be seen that the value of $t-$ count is greater than t-table then the conclusion there is a difference. So the conclusion has been proved statistically with t test and got the result that is difference of mean value between experiment class and control class.

Thus it can be said that developed multimedia in accordance with the opinion of Sanjaya (2012: 227) which says that: 1) media to be used must be in accordance with the goals to be achieved, 2) must be in accordance with learning materials, 3) must be in accordance with the needs and condition of learners, 4) must be in accordance with the ability of teachers to operate it, 5) must pay attention to the effectiveness and efficiency of the media made to be used in learning.

\section{CONCLUSIONS, IMPLICATIONS AND SUGGESTIONS}

\subsection{Conclusion}

Based on the results of research development of multimedia-based learning media that has been done, then obtained the following conclusions:

a. Multimedia-based multimedia learning products that resulted in (file, image, video, sound) for luncheon Bakery.

b. In this development research resulted in a multimedia-based learning media that is valid, practical and effective, in the courses of Bakery. Multimedia-based learning media developed based on the syllabus and jobsheet of Bakery courses.

c. Multimedia-based learning media on learning bakery has been tested and valid is 0.93 and 0.91 in the category is very valid, practical with a value of $91.42 \%$ in the category very practical and effective use as a medium of learning in the course of bakery.

d. The use of multimedia-based learning media can improve student learning outcomes by looking at differences in learning outcomes of the experimental class and control class, the experimental class learning outcomes are higher than the control class. Means this media effectively dugunakan to improve student learning outcomes.

\subsection{Implications}

This development research has resulted Multimedia-based learning media that can be used in learning the courses of Bakery. This research can give inputs to education providers, because multimedia-based learning media developed can improve the effectiveness of student learning. Lecturers can develop multimedia-based learning media so that its use is 
not only limited to the course of the course, but can be used for other courses.

The easy-to-use process for both lecturers and students is likely to increase the effectiveness and efficiency of time in the learning process so that learning will be easy to implement, interesting and fun for students. This means the implications of Multimedia-based learning media can be used to deliver learning materials and improve understanding of learning concepts.

The importance of multimedia-based learning media in the process of learning Bakery because multimedia-based learning media developed can foster creativity, innovation educators in creating a fun learning atmosphere, fostering interest and desire of students to learn with lecturers directives and independently.

\subsection{Suggestions}

Based on the research conducted, it is suggested things as follows:

a. It is suggested to other researchers to develop similar things on learning materials, both in Bakery courses and other lessons.

b. It is suggested that lecturers who teach Bakery courses, in order to help improve student learning outcomes one of them by using multimediabased learning media that has been valid, practical and effective in this learning.

c. It is suggested to FPP UNP to facilitate the use of media tools required by lecturers.

\section{REFERENCES}

Arikunto, Suharsimi. 2010. Research Procedures A Practice Approach. Jakarta: Rineka Cipta.

Djamarah, Syaiful Bahri. 2002. Teaching and Learning Strategies. Jakarta: Rineka Cipta.

Rusman, et al. 2011. Learning Based on Information and Communication Technology. Jakarta: PT. Raja Grafindo Perasada.

Sadiman, Arif. 201. Media Education: Understanding, Development and Utilization. Jakarta: PT. Raja Grafindo. Persada.

Sanjaya, Vienna. 2014. Learning Communication Media. Jakarta: Kencana.

Sugiyono. 2012. Statitiska For Research. Bandung: Alfabeta.

Sumardjoko, Bambang. 2010. FactorsDeterminan The Role Of Lecturers In Quality Guarantee Of Higher Education. (http://dowload. portalgaruda.org/article=52219\&val=445, accessed 10 January).

Trianto. 2009. Designing a Progressive Innovative Learning Model. Jakarta: Kencana.

Wena, M. 2009. Contemporary Innovative Learning Strategy An Operational Conceptual Overview. Jakarta: PT. Earth Script. 